Tropical Journal of Pharmaceutical Research September 2015; 14 (9): 1703-1712

ISSN: $1596-5996$ (print); 1596-9827 (electronic)

(C) Pharmacotherapy Group, Faculty of Pharmacy, University of Benin, Benin City, 300001 Nigeria.

All rights reserved.

Available online at http://www.tjpr.org

Original Research Article

http://dx.doi.org/10.4314/tjpr.v14i9.23

\title{
Occupational and Environmental Risks from Mancozeb in Aviation Facilities in the Banana Producing Area of Teapa, Tabasco, Mexico
}

\author{
Verónica I Domínguez-Rodríguez ${ }^{1}$, José J Obrador-Olán ${ }^{1 *}$, Randy H Adams ${ }^{2}$, \\ Joel Zavala-Cruz ${ }^{1}$, Humberto Vaquera-Huerta ${ }^{3}$, Armando Guerrero-Peña ${ }^{1}$ and \\ Edith Miranda-Cruz ${ }^{4}$ \\ ${ }^{1}$ Colegio de Postgraduados Campus Tabasco, Periferico Carlos A. Molina S/N Carr. Cardenas-Huimanguillo Km 3.5. H. \\ Cárdenas, ${ }^{2}$ Universidad Juárez Autónoma de Tabasco División Académica de Ciencias Biológicas, Carr. Vhsa-Cárdenas Km \\ 0.5 Entronque Bosques de Saloya, Villahermosa, ${ }^{3}$ Colegio de Postgraduados Campus Montecillo, ${ }^{4}$ Universidad Juárez \\ Autónoma de Tabasco División Académica de Ciencias Agropecuarias, Km 25+2 de la Carr. Vhsa-Teapa R/a La Huasteca \\ 2da. Secc. Centro, Tabasco. Mexico
}

*For correspondence: Email: obradoro@colpos.mx, dominguez.veronica@colpos.mx; Tel: +52 (937) 3724099, 3722297, (993) 3 544308, 3581500 ext. 6467

Received: 13 May 2015

Revised accepted: 2 August 2015

\begin{abstract}
Purpose: To identify occupational risks and practices in the four aerial fumigation facilities in the Sierra banana growing region and to evaluate environmental impacts from Mancozeb use.

Methods: Occupational health risks were identified and practices in the four aerial fumigation facilities in the Sierra banana growing region were documented. Semi-structured interviews were conducted with installation managers. To evaluate environmental impact, samples of water and soil were collected and analysed in an acute toxicity bioassay with Vibrio fischeri, using uncontaminated soil and water to establish background levels.

Results: Even in the largest and best-equipped facility, serious risks to workers' health were encountered from inadequate use of protective equipment by workers. Furthermore, excessive use of pesticide, lack of re-use of unused product, poor facility design and poor use of wash-water were observed, resulting in maximum toxicity of $>5$ times background in discharged water. Parallel soil samples were $>20$ times more toxic than background, being most toxic at $>0.5 \mathrm{~km}$ from the discharge point.

Conclusion: Areas of opportunity to improve worker health and the environment include proper and consistent use of protective equipment, re-use of unused product, wastewater reduction and appropriate wastewater treatment.
\end{abstract}

Keywords: Black Sigatoka, Ethylene thiourea, Fumigation, Pesticide, Mancozeb, Airports, Microtox, Vibrio fischeri, Occupational health risks, Toxicity

Tropical Journal of Pharmaceutical Research is indexed by Science Citation Index (SciSearch), Scopus, International Pharmaceutical Abstract, Chemical Abstracts, Embase, Index Copernicus, EBSCO, African Index Medicus, JournalSeek, Journal Citation Reports/Science Edition, Directory of Open Access Journals (DOAJ), African Journal Online, Bioline International, Open-J-Gate and Pharmacy Abstracts

\section{INTRODUCTION}

Agricultural production is vital to satisfy human nutritional needs but is often achieved through excessive use of pesticides, which may themselves cause risks to humans during production and consumption. In tropical regions, high humidity favours fungal growth and thus fungicide use is common for control of pre- or post-harvest disease in crops [1,2]. Among these 
crops, banana is especially important; in some areas it is considered to be one of the four main food staples after rice, wheat and milk [3]. In Mexico, Tabasco is the second most important producer of banana [4]. However, this area has been affected by the fungal disease known as Black Sigatoka (Mycosphaerella fijiensis, Morelet), growing on leaves and fruit and leaving spots, reducing the production level and commercial value of the fruit $[1,5]$. For control, Mancozeb, the ethylene bis-dithiocarbamate (EBDTC) of manganese, is used, which has moderate to acute toxicity to non-target species [6].

However, Mancozeb is spontaneously degraded in the environment by chemical oxidation, photolysis, hydrolysis and microbial metabolism to ethylene thiourea (ETU) [7], which is mutagenic [8]. Mancozeb has been found in discharge drains into the Teapa River, with toxicities double the background level [9]. This is especially problematical in the winter (norther, "nortes") season, which is accompanied by frequent but light rains, producing high ambient humidity. This area, including the Teapa and Tacotalpa municipalities of Tabasco, and the Pichucalco municipality of Chiapas, is known as the "Sierra" (mountain range) banana zone, lying at the foot of the Chiapas Mountain Range. It can have annual precipitation of $>3000 \mathrm{~mm}$ [10], favouring the growth of fungus. This has led to an ever increasing application rate of fungicide by producers, and the subsequent probability of run-off, infiltration, and aquifer contamination [2].

In this study, fumigation aerodromes serving the Sierra banana zone were characterized and occupational health risks were identified by inspection of the installations and interviews with the proprietors and managers. Also, toxicity was measured in soil and wastewater in the highest capacity aerodrome serving the region. Results were used to support recommendations put forth to achieve an adequate management of fungicide in the aviation facility itself (prefumigation).

\section{EXPERIMENTAL}

\section{Study area}

The Sierra Banana Producing Region is located in the UTM quadrant $15 \mathrm{Q}$, between coordinates 501000E, 1959000N; 510000E, 1959000N; $501000 \mathrm{E}, 1941000 \mathrm{~N}$; and 510000E $1941000 \mathrm{~N}$. With an extension of 28300 ha, it has a tropical humid climate, with rains throughout the year, an average annual precipitation of $3500 \mathrm{~mm}$ and an average annual temperature of $26^{\circ} \mathrm{C}$ [11].

The physiographical regions in the study area have been described as High Alluvial Plain (River Levee), Medium Alluvial Plain, Low-concave Alluvial Plain and Mountain zone [12]. It is worth mentioning that the study area is located in the ecogeographical unit named Interior Fluvial Plain of the Sierra River [13].

Classified according to the World Reference Base system [14], the predominant soils correspond to Fluvisols, Gleysols and Vertisols [12]. They are of medium depth and intermediate textures, with smectite and illite clays predominating, and a water table at a depth of $<2 \mathrm{~m}$. They are cultivated principally for pasture in the flattest (lowest) areas, and near the rivers, for banana, cacao, corn and sugar cane. Flooding results in accumulation of thick sediments forming river banks and natural levees up to $500 \mathrm{~m}$ wide, where the soils are well drained. Adjacent to these areas, there are isolated flood plains with minimal water flow, where finer grained minerals are deposited, characteristically gleyic in nature. In the lowest parts of these flood plains, settling basins are formed, where the water flow is minimal and in which the finest grained minerals are deposited [13].

This study was conducted with verbal permission of the aerodrome owners or operating managers: in the installation "La Pista" with permission of the manager, Agr. Eng. Francisco Javier Figueroa López, in "La Florida" with permission of the owners Productores Agrícolas de la Sierra, S.C. de R.L. de C.V., in "Monterrey", with permission from the owner, Dr. Horacio Luque, and in "Jorge Efraín" by the owner/operator Capt. José Gabriel Pérez Esquinca.

\section{Prospective visits and interviews}

Prospective visits were made to observe the conditions and water management at the aerodromes as well as to interview management personnel. The particulars of the fungicide preparation, loading and solution applications, and wastewater treatment were observed. Information collected included: plant disease most affecting fruit production, chemical control product(s) used, application type, annual fumigation cycles, doses, management and product knowledge, application description and hectares in production. Other information obtained by observation was with respect to pesticide management previous to application, and general status/upkeep of the installations. 


\section{Sampling}

In the aerodrome with the greatest coverage, discrete wastewater samples were collected at different distances from the source following the discharge canal [15], to determine toxicity. Likewise, parallel surface soil samples were collected on the canal banks [16]. Additionally, a control soil sample was obtained distant from the discharge area, to determine background soil toxicity. Samples were collected in glass jars with a Teflon seal-cap. The jars were covered in aluminium foil to avoid possible solar radiation, and labelled. They were maintained at a temperature of $<20 \stackrel{\circ}{\circ}$ during transport, to minimize possible alterations and stored in the laboratory at $4 \stackrel{\circ}{\circ} \mathrm{C}$ until analysis.

In the largest and potentially most contaminating aerodrome, toxicity samples were collected on wastewater and adjacent soil (see Figure 1 for general layout). The facility consists of two hangars, an office, the runway, a product mixing and loading area, storage facilities and a drainage canal. In Figure 1, most of the sampling points are indicated, with the exception of the farthest sampling points, at $150 \mathrm{~m}$ and 500 $\mathrm{m}$ from start of the canal, and a nearby reference (uncontaminated) soil, due to scale limitation.

\section{Toxicity analysis}

To evaluate environmental impacts, acute toxicity was analysed in water and soil using the Microtox ${ }^{\circledR}$ bioassay, using a bioluminescent bacterium (Vibrio fischeri, previously classified as Photobacterium phosphoreum) as the test organism [17]. Upon being subjected to potentially toxic samples, the light production of the bacteria is measured and compared to a blank.

\section{Data analysis}

Effective concentration-50 ( $\left(\mathrm{CC}_{50}\right)$ was calculated for soil samples, which corresponds to the concentration of sample in a dilution which produces a reduction of $50 \%$ in the bioluminescence, as compared to a blank. Toxicity Units (TU) were calculated thus: $T U=1 / E C_{50}$, when $E C_{50}$ is represented as a proportion (i.e., $E_{50}$ of $100,000 \mathrm{ppm}$ is equivalent to 0.1 as a proportion; TU $=1 / 0.1=$ 10). Toxicity of contaminated test samples were compared to uncontaminated soil of the same type from the study area to discern if the toxicity observed in the test sample was indeed due to fungicide (Mancozeb) contamination, or if it merely reflected natural, background levels.
For water samples, the bioluminescence corresponding to $100 \%$ sample was calculated and compared to the scale developed by Kross and Cherryholmes for leachates [18], based on the assumption that uncontaminated water essentially has no toxicity.

\section{RESULTS}

\section{Pesticide management-field observations}

According to interviews, the most important banana disease in the area is Black Sigatoka (Mycosphaerella fijiensis, Morelet). The principal product used to control the fungus by aerial fumigation is Mancozeb, the ethylene bisdithiocarbamate of magnesium and zinc (CAS No. 8018-01-7, CIPAC No. 34, UNO No. 3077). According to aerodrome management personnel, the fungicide is applied in the study area at $2 \mathrm{~kg}$ $\mathrm{ha}^{-1}$. It is administered in solution, with $7.3 \%$ $(\mathrm{w} / \mathrm{v})$ Mancozeb and $1.8 \%(\mathrm{w} / \mathrm{v})$ of pine resin (an emulsifier), with an application of 42 to 50 times annually. Most of the year, Mancozeb is applied once a week, but during the "norther" season, it is applied twice a week.

In the aerodromes visited, Mancozeb was found in $50 \mathrm{~kg}$ sacks, which are dumped by workers into mixers of a little over $5500 \mathrm{~L}$ capacity. In the mixers, the product plus resin is mechanically mixed in water, and pumped through hoses to the aircraft. The workers have at their disposal complete personal protective equipment. Nonethe-less, they use only long sleeve overalls and rubber boots as protective equipment (which is not in compliance with the recommendations on the Material Safety Data Sheet for the product). The planes are sprayed down and cleaned with soap and water periodically during the morning fumigation routine, and after the fumigation session is over. During these additional activities, the workers still only use overalls and rubber boots.

On the positive side, two of the four operators in the area, including the largest, use GPS for programmed delivery of product, thereby reducing unintended spraying. The area fumigated by the four facilities in the area is $\sim 10500$ ha including Teapa, Tacotalpa and Pichucalco municipalities. To serve this area at the above mentioned aerial application rate, it is necessary to use up to 1092 tons of Mancozeb annually. 


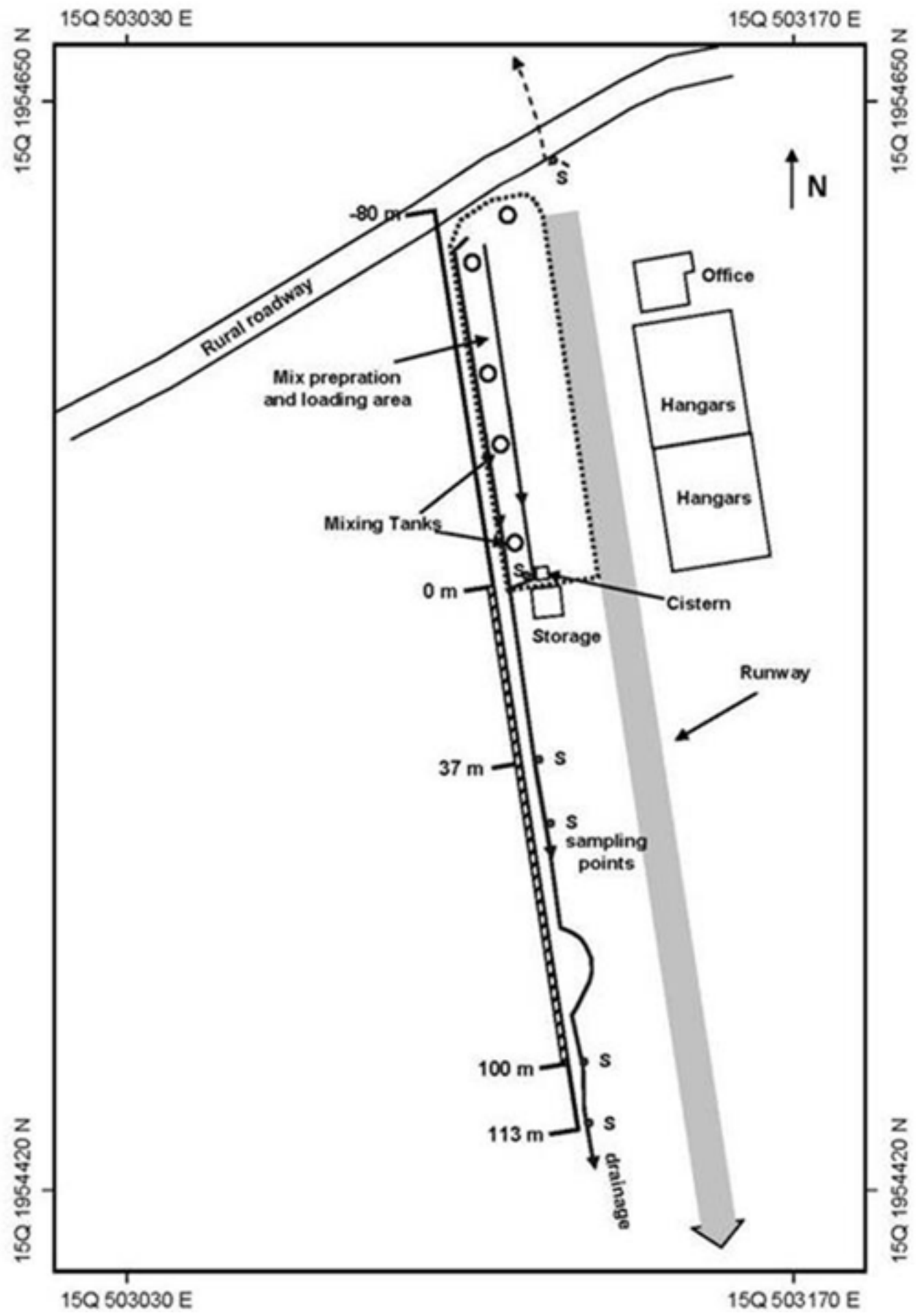

Figure 1: Distribution of sampling points in the major aviation fumigation facility

\section{Toxicity analysis}

Data for wastewater and soil toxicity are presented in Tables 1 and 2, and Figure 2. In this scheme, the mixing tank area is considered the source area, located about $30 \mathrm{~m}$ up-gradient from the beginning of the wastewater discharge canal. From the mixing tank area to the start of the discharge canal there is an increase in bioluminescence in the wastewater, corresponding to a reduction in toxicity. In this area, besides the loading of product in the planes, washing of the planes as well as the mixing tanks themselves takes places, which was measured in the field to use $\sim 7450 \mathrm{~L}$ during each morning work period. 
Table 1: Toxicity of wastewater samples

\begin{tabular}{|c|c|c|c|}
\hline Season & Location & $\begin{array}{c}\text { \% Bioluminescence } \\
\text { (100\% sample) }\end{array}$ & Toxicity \\
\hline $\begin{array}{l}\text { Summer rainy } \\
\text { season }\end{array}$ & Mix tank & 0 & Very toxic \\
\hline (Jun-2011) & $\begin{array}{c}150 \mathrm{~m} \text { (discharge } \\
\text { canal) }\end{array}$ & 19 & Very toxic \\
\hline \multirow[t]{5}{*}{$\begin{array}{l}\text { Winter } \\
\text { (Jan-2012) }\end{array}$} & $0 \mathrm{~m} \begin{array}{c}\text { (discharge } \\
\text { canal) }\end{array}$ & 70 & Slightly toxic \\
\hline & $\begin{array}{c}37 \mathrm{~m} \text { (discharge } \\
\text { canal) }\end{array}$ & 77 & Slightly toxic \\
\hline & $\begin{array}{c}113 m \text { (discharge } \\
\text { canal) }\end{array}$ & 38 & Toxic \\
\hline & $\begin{array}{c}500 \text { m (discharge } \\
\text { canal) }\end{array}$ & 100 & Non-toxic \\
\hline & North road drain & 100 & Non-toxic \\
\hline
\end{tabular}

Table 2: Toxicity in sediment samples

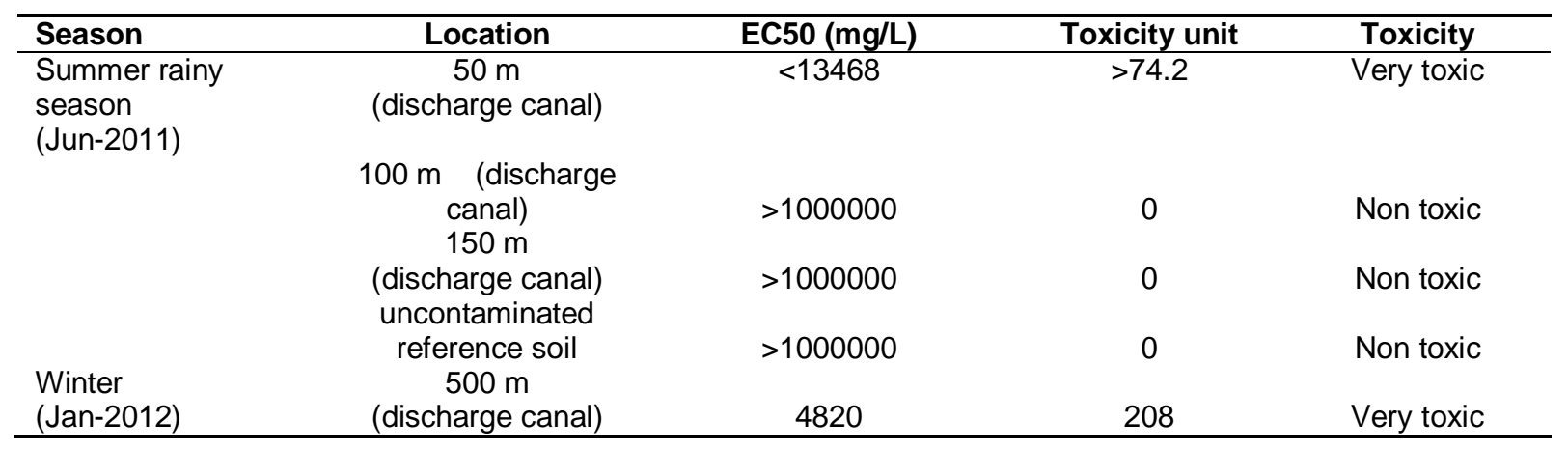

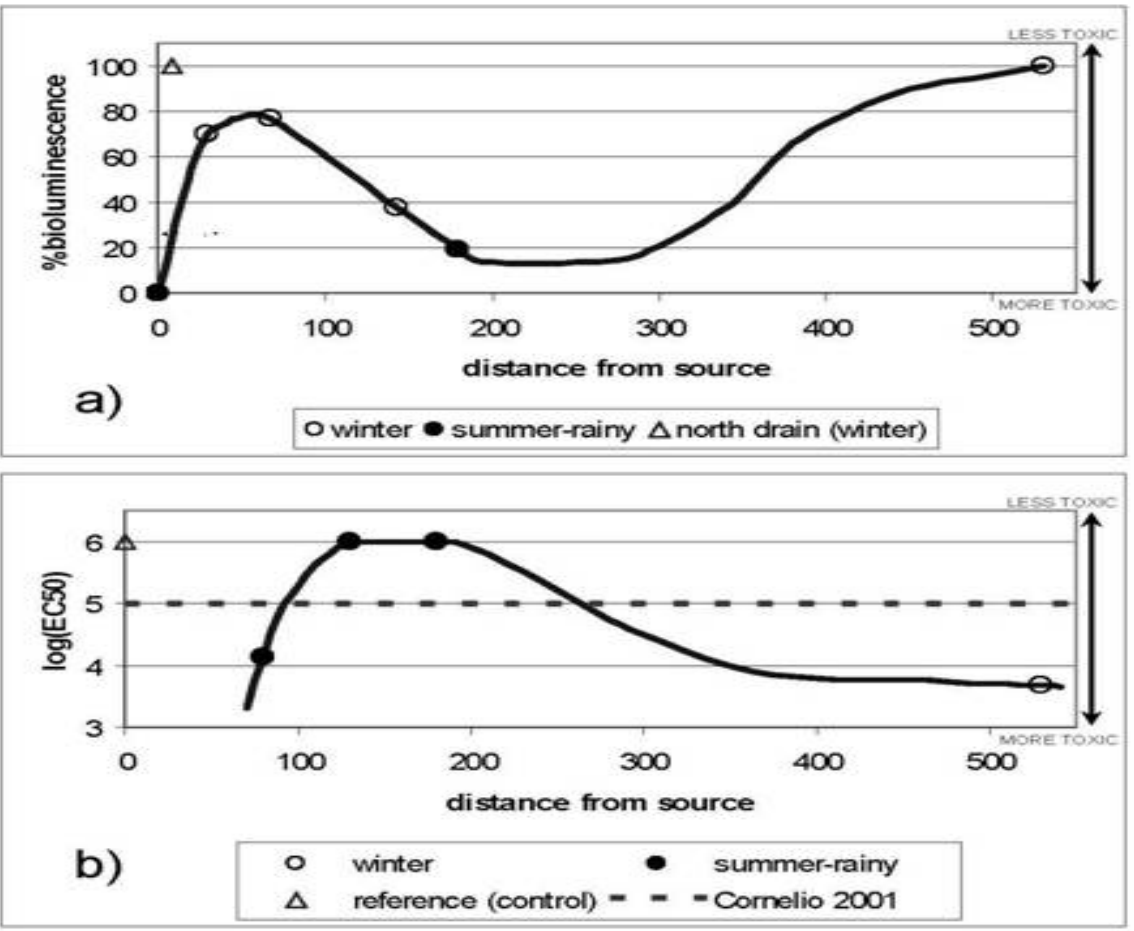

Figure 2: Relationship between toxicity and distance from source in water and sediment. a) Percent bioluminescence in $100 \%$ samples of wastewater. b) Logarithmic scale of Effective Concentration-50 in soil samples. The dotted line is the non-toxic reference level from the same area [9]. For both graphs, the mixing tank area was taken as the source starting point 


\section{DISCUSSION}

The major banana disease found in this area, Black Sigatoka (Mycosphaerella fijiensis, Morelet), is a foliar disease caused by a fungus that grows in the leaves and fruit, spotting it and reducing the commercial value $[1,5]$. The principal chemical used to control this disease, Mancozeb, has a protective action for the plant, and only a short half-life of approximately 15-21 days. In humans it is an irritant to skin, eyes and mucous membranes, and can be noxious by ingestion, inhalation and by absorption through the skin $[19,20]$. Under certain conditions, it can emit inflammable vapours and cause violent and explosive reactions. Its principal degradation product, ethylene thiourea (ETU), is considered mutagenic, teratogenic and antithyroidic in humans [21], and there are numerous reports of high toxicity of ETU in fish [19]. Thus, although Mancozeb itself is not classified as carcinogenic, its principal degradation product is (see Table 3 ).

One study in another tropical area demonstrated that after applying Mancozeb to soil, the ETU concentration continued to increase for up to 30 days before declining, due to natural attenuation [22]. Considering the application frequency used in the subject area in the present study (approximately weekly), it is assumed that ETU will accumulate, creating risks of adverse effects to human health and environment (see Table 3). In many countries Mancozeb has been prohibited (e.g. Belize and California, USA), and some users in Ecuador have been sued for poor management and impacts to worker safety [23]. It is listed as a hazardous chemical in the United States and as potentially dangerous to worker health and safety [24]. According to the manufacturers, extra care must be taken to skin, eye and inhalation exposure, and it should not be stored in fumigation facilities $[25,26]$. However, we observed that although in some of the aerodromes the product was transported from the supplier to the aviation facilities early in the morning for same-day application; in others the product was indeed stored for subsequent use.

Likewise, only some of the facilities have registered themselves in the Campo Limpio ("clean countryside") program. This program (Programa Nacional de Recolección de Envases Vacíos de Agroquímicos y Afines "Conservemos un Campo Limpio") is administered by the National Service of Health, Safety and Agricultural Food Quality (SENASICA) a dependency of the Ministry of Agriculture, Livestock, Rural Development, Fishing and Food [26]. The purpose of the program is the recollection and adequate disposal of empty agrochemical packaging material (bottles and sacks) [27].

The amount of fungicide administered in the study area is equivalent to $84-100 \mathrm{~kg} \mathrm{ha}^{-1}$ year $^{-1}$, which is triple the level permitted for integrated production in some countries, for example, by the National Institute of Agriculture and Livestock Research, Uruguay [28]. It is worrying to think that in countries in which this product has been restricted, the fumigation dose is only $1 \mathrm{~kg} \mathrm{ha}^{-1}$ with only 22 applications annually. Thus, in the study area the actual application rate is roughly four times that which has already been restricted in other countries.

This application frequency practically assures the accumulation of Mancozeb and ETU [2]. Nonetheless, it appears that the product users are unaware of this potentiality. They manifest a confident attitude with respect to product use, mentioning that it is only "slightly toxic and does not present a risk". It is assumed that this attitude is due to the lack of knowledge about the potential risks of Mancozeb to human health that can occur with its excessive use, as well as the confidence of facility workers. This, coupled with the high temperature and humidity in the region, which makes the use of more complete protective equipment uncomfortable (such as masks, goggles, aprons and gloves), may be the reason that aerodrome workers do not use adequate security equipment.

On the positive side, the use of GPS for programmed delivery of the product in the field, used by two of the four aerodromes, reduces spraying of unintended areas (including schools and residential areas),

Table 3: Potential exposure pathways and noxious effects for Mancozeb and ETU

\begin{tabular}{lll}
\hline \multirow{2}{*}{ Exposure pathway } & \multicolumn{2}{c}{ Chemical } \\
\cline { 2 - 3 } & Mancozeb & ETU \\
\hline Skin and eyes (contact) & Irritation & Irritation \\
Ingestion & Psychomotor system damage, tumors & Thyroid damage \\
Inhalation & Irritation of respiratory pathways, & Thyroid damage, tumors \\
& psychomotor system damage & \\
\hline
\end{tabular}


and also the occupational exposure of flagmen in the field. Unfortunately, those operators that do not use this system may cause co-spraying of unintended areas [29].

The toxicity level scale used here is that proposed for leachate water by Kross and Cherryholmes, using a quarter-log scale based on the inhibition of bioluminescence in undiluted wastewater (100\% sample) [18], and on the assumption that natural, uncontaminated water (rain, streams, etc.) is non-toxic. According to these authors, the indeterminate range (according to the precision of the method) corresponds to $\sim 1-10 \%$ reduction in bioluminescence in $100 \%$ samples; $10 \%$ being $\sim 1 \%$ in the logarithmic scale.

For soil and sediment samples a different scale was used, based on a modification of the scale proposed by Kross and Cherryholmes [18], as used and elaborated by Cornelio [9]. The potential background toxicity to the test organism is taken into consideration, since there may be naturally occurring toxic compounds in the soil which affect the test organism, a bacterium of marine origin and not from soil. The quarter-log scale is normalized based on the background toxicity of regional soils from Tabasco State.

From the mixing area to the discharge canal, there is an increase in bioluminescence, corresponding to a reduction in toxicity. It is probably due mainly to dilution. In this area, the planes are washed, and the toxicity may be diluted with the excess water $(7450 \mathrm{~L} /$ work period). Between $30-67 \mathrm{~m}$, a little more reduction in toxicity (increase in bioluminescence) is observed, possibly due to more dilution, chemical and photo-degradation. Subsequently, between $67-180 \mathrm{~m}$, the toxicity increases, conceivably from the transformation of Mancozeb into ETU (which is more toxic) in the discharge canal itself. Finally, between $180-$ $530 \mathrm{~m}$, the toxicity is eliminated in the wastewater. This may be in part from degradation of the Mancozeb and ETU, as well as precipitation from the water into the sediments.

Observing the toxicity pattern in the parallel soil samples, a similar tendency is noticed but delayed. When wastewater in the drain starts to show less toxicity, after about $200 \mathrm{~m}$ from the source, the toxicity in nearby soil increases. This may indicate sedimentation of toxic compounds (such as ETU) and toxicity reduction in water. However, at $0.5 \mathrm{~km}$ from the source, the soil is still very toxic, and will likely continue to be source of secondary surface water and/or ground water contamination (surface run-off, infiltration). Thus, although the surface water is essentially non-toxic, the potential for continued toxicity from the contaminated sediments may be an important environmental risk.

In light of the results obtained, and considering the importance of banana production for the region, it is important to carryout fumigation activities sustainably, such that worker's health is preserved. For this purpose, we have developed the following recommendations to implement in the aviation facilities.

1. A large reduction in the volume of wastewater generated with Mancozeb is required, through judicious use and re-use of residual product, according to the Manual for the Training Course on Risks due to Pesticide Use [30], as well as infrastructure changes.

2. Implementation of wastewater treatment technology to avoid contamination of soil and groundwater. The biobed technology developed in Sweden [31], may be particularly useful, but it is recommended that it only be put into practice after a large reduction in wastewater volume has been achieved.

3. Facility workers need to be trained according to the Manual for the Training Course on Risks due to Pesticide Use (Curso de Capacitación Sobre el Riesgo por el Uso de Plaguicidas) [30].

4. Conditions in the fumigation facilities should be in accordance with Convention No. 184 on Health and Safety in Agriculture [32], along with Recommendation No. 192, which states that waged agricultural workers, are guaranteed in international law the same rights and levels of protection as other categories of workers.

5. The disposal of containers used for pesticides and co-adjuvants should be in accordance the "Campo Limpio" (Clean Countryside) program coordinated by the Ministry of Agriculture, Livestock, Rural Development, Fishing and Food through the National Service of Health [26], Safety and Agricultural Food Quality (SENASICA), and based in the General Law for the Prevention and Integral Management of Wastes [33].

\section{Periods of de-toxification for workers.}

7. Reduction in the quantities of Mancozeb applied, considering the different seasons of the year, with reductions especially in the dry season when the humidity, and thus fungal growth, is reduced. During this period the application may 
not be especially productive, but only cause secondary effects in nearby communities.

8. Great care should be taken to reduce secondary exposure due to rainy or windy conditions in which product may be washed away and/or dispersed by wind, causing a less effective pesticide application, but greater secondary effects in the community.

By these means, one can contribute to the reduction (or possible prevention) of soil and water contamination and achieve the resulting benefits, as well as comply with several points established in the Federal Law on Vegetable Health [34].

\section{Limitations of the study}

Although this study clearly demonstrates the risk to environment and public health due to exposure of carbamate pesticide, additional work is still needed to more clearly define the risk. Especially important is a prolonged study on the Mancozeb and ETU dynamics in the soil and water with respect to accumulation and dissipation, potential for cancer risks and long term chronic effects. This would be important in the major aerodrome in the region, and should be complemented by studies in the secondary aerodromes. Also, more research into effective but low-cost management and treatment schemes is needed to reduce effluent discharge. It is especially important that these methods be logistically and economically feasible considering local social customs and economics.

\section{CONCLUSION}

Specific difficulties with the proper management of fungicide were observed, even in the largest and best-equipped aviation fumigation facilities. Areas of opportunity are identified with respect to improvements in occupational hygiene, product re-use, wastewater reduction, and wastewater treatment. There is toxicity in the wastewater discharge area which suggests transformation of Mancozeb to ETU as well as sedimentation of toxic products in the discharge canal, which may be a long-term source of secondary contamination to soil, surface water and groundwater. General and specific actions will be needed to mitigate this situation and reduce risk to workers and the environment.

\section{ACKNOWLEDGEMENT}

Thanks to the personnel at the following aerodromes for site access and information on the preparation and use of fungicides: Agr. Eng. Francisco Javier Figueroa López of the installation "La Pista", the owners of Productores Agrícolas de la Sierra, S.C. de R.L. de C.V. in "La Florida", Dr. Horacio Luque of "Monterrey", and Capt. José Gabriel Pérez Esquinca in "Jorge Efraín". Same goes to the Colegio de Posgraduados, especially the Cárdenas, Tabasco Campus, and the Remediation Laboratory of the Universidad Juárez Autónoma de Tabasco, for logistical and financial support.

\section{REFERENCES}

1. Contreras M. El Chamusco Negro (Sigatoka), una Nueva Enfermedad de la Hoja de los Plátanos. Rev. Geogr, Agric. 1982; 4: 61-102.

2. Geissen V, Que RFJ, Bastidas BP, Díaz GG, Bello MR, Huerta LE, Ruiz SLE. Soil and Water Pollution in a Banana Production Region in Tropical Mexico. Bull Environ Contam Toxicol. 2010. 85: 407-413

3. Vázquez CRA, Romero CJ, Figueroa V, Munro OD. Paquete Tecnológico para el Cultivo de Plátano. Colima, México: Gobierno del Estado de Colima; 2005; $p 72$

4. Gobierno del estado de Tabasco. Plan Rector Sistema Producto Plátano en el Estado de Tabasco. Villahermosa, Tabasco. México: Gobierno del estado de Tabasco; 2006; 33pp.

5. Castañeda CR, Cámara CJ, La Agricultura en Tabasco. Universidad Juárez Autónoma de Tabasco. Villahermosa, Tabasco, México. 1992 pp 164.

6. Barberá C. Pesticidas Agrícolas, $3^{\underline{a}}$ edición. Barcelona, España: Omega Ediciones S.A. 1976.

7. Xu S. Environmental fate of Mancozeb. California department of pesticide regulation. E. U. 2000.

8. Domínguez MC, Peñuela G, Flórez MT. Método Analítico para la Determinación de Etilentiourea (ETU) Subproducto del Mancozeb en un Andisol del Oriente Antioqueño. Rev. Fac. Ing. Univ. Antioquia. 2009; 49: 42-49.

9. Cornelio GY, Evaluación Preliminar de Toxicidad por Plaguicidas (Mancozeb) en Agua y Sedimentos en la Zona Platanera del Río Teapa, Tabasco, México. [dissertation] [México]: Universidad Juárez Autónoma de Tabasco. Villahermosa, Tabasco, México; 2001; $p$ 103.

10. Aceves NLA, Juárez LJF, Palma LDJ, Rivera HB, Rincón RJA, Morales CR, Hernández AR, Martínez SA, Hernández SJL.. Estudios para Determinar Zonas de Alta Potencialidad de los Cultivos en el Estado de Tabasco. Informe General. Secretaría de Desarrollo Agropecuario Forestal y Pesca Villahermosa, Tabasco, México. 2008; $p 65$.

11. Instituto Nacional de Estadística, Geografía e Informática (INEGI). Síntesis Geográfica del Estado de Tabasco y Anexo Cartográfico. Gobierno del Estado de Tabasco. Aguas Calientes, México. 2001; p 118.

Trop J Pharm Res, September 2015; 14(9): 1710 
12. Palma LDJ, D.J. Cisneros, Moreno C.E, Rincón RJJ. Suelos de Tabasco: Su Uso y Manejo SustenTable. Gobierno del Estado de Tabasco. Villahermosa, Tabasco, México. 2007; p 120.

13. Ortíz PMA, Siebe CC, Cram S. Diferenciación Ecogeográfica de Tabasco. In Biodiversidad del Estado de Tabasco. Bueno J, Álvarez F, Santiago S. Editors. Instituto de Biología, UNAM-CONABIO. México, D.F. 2005; pp 305-322.

14. IUSSS International Union of Soil Science Societies. World Reference Base Working Group. First Edition. Report on World Soil Resources No. 103. FAORome. 2007.

15. Secretaría de Comercio y Fomento Industrial (SECOFI). Norma Mexicana NMX-AA-003-1980 Aguas Residuales - Muestreo. Residual Waters-Sampling. Dirección General de Normas. México, D.F. 1980; $p$ 8.

16. Secretaria de Medio Ambiente y Recursos Naturales (SEMARNAT). Norma Oficial Mexicana NOM-021RECNAT-2000 que EsTablece las Especificaciones de Fertilidad, Salinidad y Clasificación de Suelos, Estudio, Muestreo y Análisis. Diario Oficial de la Federación. México, D.F. 2002; $p 85$.

17. Secretaría de Comercio y Fomento Industrial (SECOFI). Norma Mexicana NMX-AA-112-1995-SCF Análisis de Agua y Sedimentos-Evaluación de Toxicidad Aguda con Photobacterium Phosphoreum - Método de Prueba. Water and Sediment Analysis - Acute Toxicity Evaluation with Photobacterium Phosphoreum - Test Method. México: Dirección General de Normas. México, D.F. 1996; $p 33$.

18. Kross, B.C. and, K. Cherryholmes. Toxicity Screening of Sanitary Landfill Leachates: A Comparative Evaluation with Microtox Analyses, Chemical, and other Toxicity Screening Methods. In Ecotoxicology Monitoring; Richardson M. L. VCH Publishers. Weinheim, Germany: 1993. pp: 225-249.

19. USEPA United States Environmental Protection Agency. Risks of Mancozeb and Maneb Uses to the Federally Listed California Red Legged Frog (Rana aurora draytonii), Pesticide Effects Determination. Environmental Fate and Effects Division, Office of Pesticide Programs, Washington, D.C. 20460. 2007; p 143.

20. Mancozeb Pesticide Information Profile. Extension Toxicology Network (EXTOXNET). [Pesticide Management Education Program (PMEP)]. Cornell University, Ithaca, NY. Sept. 1993. [Cited: 2013 August 12]. Available from: http://pmep.cce.cornell.edu/profiles/extoxnet/haloxyfo p-methylparathion/Mancozeb-ext.htmI\#19.

21. Houeto $P$, Bindoula G, Hoffman JR. Ethylenebisdithiocarbamates and Ethylenethiourea: Possible Huamn Health Hazards. Environmental HealthPerspectives. 1995. 105(6): 568-573.

22. Hanumantharaju TH and MD Awasthi. Persistence and degradation of metalaxyl, Mancozeb fungicides and its metabolite ethylenethiourea in soils. J Environ Sci Eng. 2004. 46(4): 312-221.

23. Breilh H, Campaña A, Maldonado A. Peritaje a la salud de los trabajadores de aerofumigacion en plantaciones bananeras, Guayas, El Oro y los Ríos. Centro Boliviano de Estudios Multidisciplinarios (CEBEM). Ecuador. 2007.

24. Vondozeb RTECS \#: ZB3200000. The Registry of Toxic Effects of Chemical Substaces. Center for Disease Control and Prevention (CDC). [National Institute of Occupational Safety and Health (NIOSH)]. 2009. [Cited: 2013 August 12]. Available from: http://www.cdc.gov/noish-rtecs/zb30d400.html

25. Material Safety Data Sheet - Protect DFTM/Mancozeb 75\%. [Cleary Chemical Corporation]. Cleary Chemical Corporation; 2003. [Cited: 2013 August 12]. Available from: http://www.cdms.net/ldat/mp78G001.pdf.

26. Ficha de datos de seguridad R. D. River Fungicida Rojas. Mancozeb [River Canarias Industrial, S.A.]. River Canarias Industrial, S.A; 2001. [Cited: 2013 August 12]Available From: http://www.river-canarias.com/ fichaspdf/funroyas.pdf.

27. Secretaría de Agricultura, Ganadería, Desarrollo Rural, Pesca y Alimentación (SAGARPA), Términos de Referencia para la Operación del Programa Nacional de Recolección de Envases Vacíos de Agroquímicos y Afines "Conservemos un Campo Limpio". México, D.F. 2009 agosto 13; $p 10$.

28. Normas para la Producción Integrada de Manzano Temporada 2005-2006. [Instituto Nacional de Investigación Agropecuaria (INIA)], Instituto Nacional de Investigación Agropecuaria; 2005. [Cited: 2013 August 23]. Available from: http://www.inia.org.uy/online/site/base_npi.php?bus= Manzano\&base $=76 \&$ imageField $. x=68 \&$ imageField $. y=$ 7. $p 45$.

29. ATSDR Agencia para Sustancias Tóxicas y el Registro de Enfermedades. Reseña toxicológica de las piretrinas $y$ los piretroides. Atlanta, GA: Departamento de Salud y Servicios Humanos de EE.UU., Servicio de Salud Pública. 2003.

30. Carpeta del Capacitador. Curso de "Capacitación a Capacitadores sobre el Riesgo por el uso de Plaguicidas. [Comisión Federal para la Protección contra Riesgos Sanitarios (COFEPRIS)], Comisión Federal para la Protección contra Riesgos Sanitarios; 2004. [Cited: 2013 September 18]. Available from: http://www.cofepris.gob.mx/Paginas/Biblioteca\&20Virt ual/Libros\%30Electronicos/ColecciónCOFEPRIS.aspx.

31. Castillo MdP, Torstensson L, Stenström J. Biodeds for Environmental Protection from Pesticide Use: a Review. J. Agrc. Food Chem 2008; 56(15):62066219.

32. Hurst $P$, Kirby $P$. Health, Safety and Environment, $A$ Series of Trade Union Education Manuals for 
Agricultural Workers. International Labour Office. Geneva, Switzerland. 2004; $p 44$.

33. Diario Oficial de la Federación (DOF), Cámara de Diputados del H. Congreso de la Unión, Secretaría General, Secretaría de Servicios Parlamentarios. Ley General para la Prevención y Gestión Integral de los Residuos. México. D. F. 2013; p 46.
34. Diario Oficial de la Federación (DOF). Cámara de Diputados del H. Congreso de la Unión, Secretaría General, Secretaría de Servicios Parlamentarios. Ley Federal de Sanidad Vegetal, México, D.F. 2011; p 36 . 